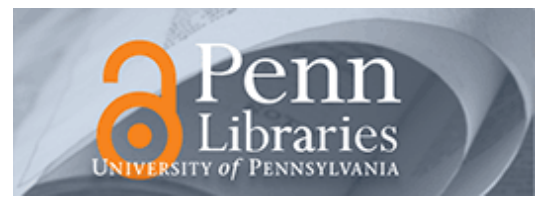

Studies in Visual Communication

Volume 4

Issue 2 Winter 1977

Article 3

1977

\title{
Margaret Mead and Gregory Bateson on the Use of the Camera in Anthropology
}

\section{Recommended Citation}

(1977). Margaret Mead and Gregory Bateson on the Use of the Camera in Anthropology. 4 (2), 78-80.

Retrieved from https://repository.upenn.edu/svc/vol4/iss2/3

This paper is posted at ScholarlyCommons. https://repository.upenn.edu/svc/vol4/iss2/3

For more information, please contact repository@pobox.upenn.edu. 
Margaret Mead and Gregory Bateson on the Use of the Camera in Anthropology 


\section{MARGARET MEAD AND GREGORY BATESON ON THE USE OF THE CAMERA IN ANTHROPOLOGY}

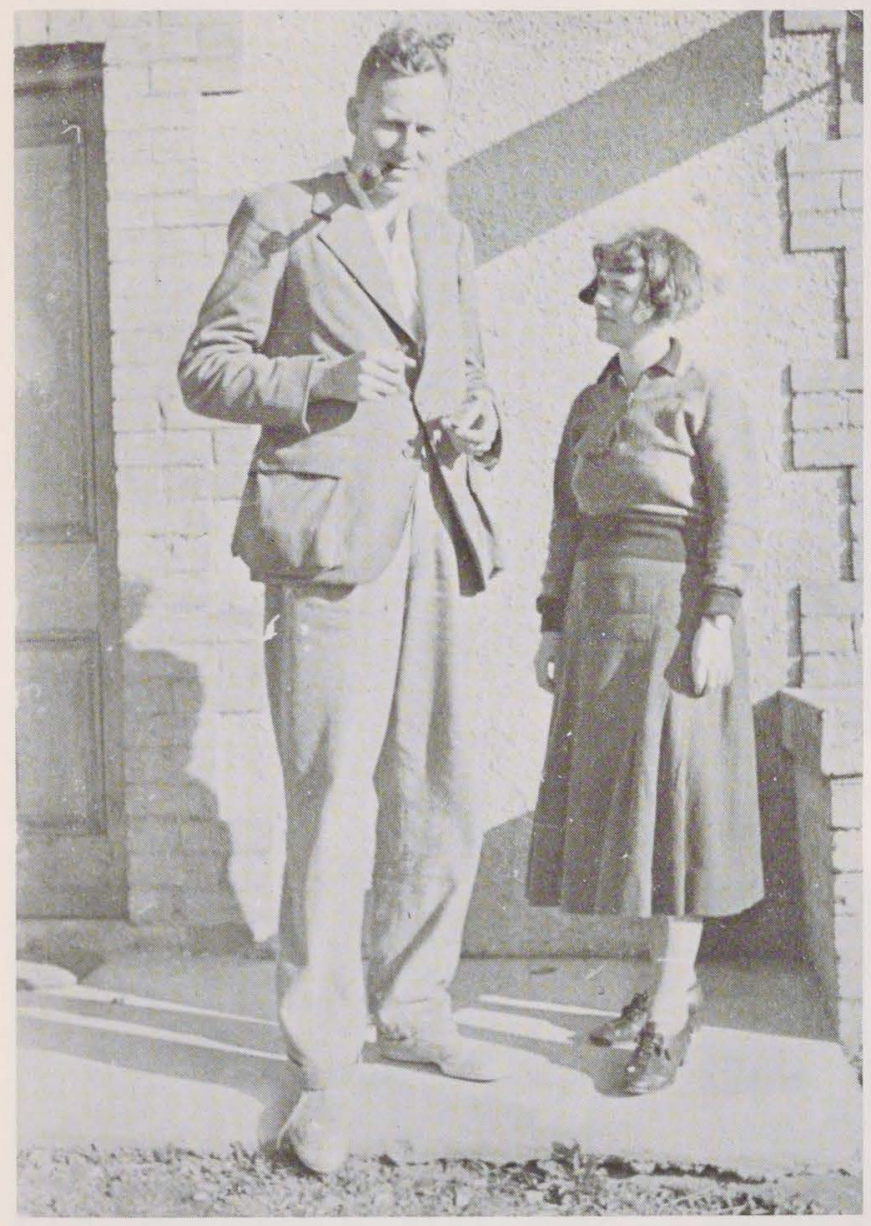

Gregory Bateson and Margaret Mead, circa 1938

[photo by Conrad Waddington]

[Editor's note: The following was excerpted from "For God's Sake, Margaret, Conversation with Gregory Bateson and Margaret Mead," printed in The CoEvolution Quarterly, Vol. 10/21, June 1976.]

Bateson: I was wondering about looking through, for example, a camera.

Mead: Remember Clara Lambert and when you were trying to teach her? That woman who was making photographic studies of play schools, but she was using the camera as a telescope instead of as a camera. You said, "She'll never be a photographer. She keeps using the camera to look at things." But you didn't. You always used a camera to take a picture, which is a different activity.

Bateson: Yes. By the way, I don't like cameras on tripods, just grinding. In the latter part of the schizophrenic project, we had cameras on tripods just grinding.
Mead: And you don't like that?

Bateson: Disastrous.

Mead: Why?

Bateson: Because I think the photographic record should be an art form.

Mead: Oh why? Why shouldn't you have some records that aren't art forms? Because if it's an art form, it has been altered.

Bateson: It's undoubtedly been altered. I don't think it exists unal tered.

Mead: I think it's very important, if you're going to be scientific about behavior, to give other people access to the material, as comparable as possible to the access you had. You don't, then, alter the material. There's a bunch of film makers now that are saying, "It should be art," and wrecking everything that we're trying to do. Why the hell should it be art?

Bateson: Well, it should be off the tripod.

Mead: So you run around.

Bateson: Yes.

Mead: And therefore you've introduced a variation in to it that is unnecessary.

Bateson: I therefore got the information out that I thought was relevant at the time.

Mead: That's right. And therefore what do you see later?

Bateson: If you put the damn thing on a tripod, you don't get any relevance.

Mead: No, you get what happened.

Bateson: It isn't what happened.

Mead: I don't want people leaping around thinking that a profile at this moment would be beautiful.

Bateson: I wouldn't want beautiful.

Mead: Well, what's the leaping around for?

Bateson: To get what's happening.

Mead: What you think is happening.

Bateson: If Stewart reached behind his back to scratch himself, I would like to be over there at that moment.

Mead: If you were over there at that moment you wouldn't see him kicking the cat under the table. So that just doesn't hold as an argument.

Bateson: Of the things that happen, the camera is only going to record one percent anyway.

Mead: That's right.

Bateson: I want that one percent on the whole to tell.

Mead: Look, I've worked with these things that were done by artistic film makers, and the result is you can't do any thing with them.

Bateson: They're bad artists, then.

Mead: No, they're not. I mean, an artistic film maker can make a beautiful notion of what he thinks is there, and you can't do any subsequent analysis with it of any kind. That's been the trouble with anthropology, because they had to trust us. If we were good enough instruments, and we said the people in this culture did something more than the ones in that, if they trusted us, they used it. But there was no way of probing further into the material. So we gradually developed the idea of film and tapes.

Bateson: There's never going to be any way of probing further into the material.

Mead: What are you talking about, Gregory? I don't know what you're talking about. Certainly, when we showed 
that Balinese stuff that first summer there were different things that people identified-the limpness that Marion Stranahan identified, the place on the chest and its point in child development that Erik Erikson identified. I can go back over it, and show you what they got out of those films. They didn't get it out of your head, and they didn't get it out of the way you were pointing the camera. They got it because it was a long enough run so they could see what was happening.

SB: What about something like that Navajo film, Intrepid Shadows? [see Worth and Adair 1972].

Mead: Well, that is a beautiful, an artistic production that tells you something about a Navajo artist.

Bateson: This is different, it's a native work of art.

Mead: Yes, and a beautiful native work of art. But the only thing you can do more with that is analyze the film maker, which I did. I figured out how he got the animation into the trees.

Bateson: Oh yes? What do you get out of that one?

Mead: He picked windy days, he walked as he photographed, and he moved the camera independently of the movement of his own body. And that gives you that effect. Well, are you going to say, following what all those other people have been able to get out of those films of yours, that you should have just been artistic?

SB: He's saying he was artistic.

Mead: No, he wasn't. I mean, he's a good film maker, and Balinese can pose very nicely, but his effort was to hold the camera steady enough long enough to get a sequence of behavior.

Bateson: To find out what's happening, yes.

Mead: When you're jumping around taking pictures. . .

Bateson: Nobody's talking about that, Margaret, for God's sake.

Mead: Well.

Bateson: I'm talking about having control of a camera. You're talking about putting a dead camera on top of a bloody tripod. It sees nothing.

Mead: Well, I think it sees a great deal. I've worked with these pictures taken by artists, and really good ones. . .

Bateson: I'm sorry I said artists; all I meant was artists. I mean, artists is not a term of abuse in my vocabulary.

Mead: It isn't in mine either, but I. . .

Bateson: Well, in this conversation, it's become one.

Mead: Well, I'm sorry. It just produces something different. I've tried to use Dead Birds, for instance. . . [see Gardner 1964].

Bateson: I don't understand Dead Birds at all. I've looked at Dead Birds, and it makes no sense.

Mead: I think it makes plenty of sense.

Bateson: But how it was made I have no idea at all.

Mead: Well, there is never a long enough sequence of anything, and you said absolutely that what was needed was long, long sequences from one position in the direction of two people. You've said that in print. Are you going to take it back?

Bateson: Yes, well, a long sequence in my vocabulary is twenty seconds.

Mead: Well, it wasn't when you were writing about Balinese films. It was three minutes. It was the longest that you could wind the camera at that point.
Bateson: A very few sequences ran to the length of the winding of the camera.

Mead: But if at that point you had had a camera that would run twelve hundred feet, you'd have run it.

Bateson: I would have and I'd have been wrong.

Mead: I don't think so for one minute.

Bateson: The Balinese film wouldn't be worth one quarter.

Mead: All right. That's a point where I totally disagree. It's not science.

Bateson: I don't know what science is, I don't know what art is.

Mead: That's all right. If you don't, that's quite simple. I do. (To Stewart:) With the films that Gregory's now repudiating that he took, we have had twenty-five years of re-examination and re-examination of the material.

Bateson: It's pretty rich material.

Mead: It is rich, because they're long sequences, and that's what you need.

Bateson: There are no long sequences.

Mead: Oh, compared with anything anybody else does, Gregory.

Bateson: But they're trained not to.

Mead: There are sequences that are long enough to analyze. . .

Bateson: Taken from the right place!

Mead: Taken from one place.

Bateson: Taken from the place that averaged better than other places.

Mead: Well, you put your camera there.

Bateson: You can't do that with a tripod. You're stuck. The thing grinds for twelve hundred feet. It's a bore.

Mead: Well, you prefer twenty seconds to twelve hundred feet.

Bateson: Indeed, I do.

Mead: Which shows you get bored very easily.

Bateson: Yes, I do.

Mead: Well, there are other people who don't, you know? Take the films that Betty Thompson studied [see Thompson 1970]. That Karbo sequence-it's beautifulshe was willing to work on it for six months. You've never been willing to work on things that length of time, but you shouldn't object to other people who can do it, and giving them the material to do it.

There were times in the field when I worked with people without filming, and therefore have not been able to subject the material to changing theory, as we were able to do with the Balinese stuff. So when I went back to Bali I didn't see new things. When I went back to Manus, I did, where I had only still photographs. If you have film, as your own perception develops, you can re-examine it in the light of the material to some extent. One of the things, Gregory, that we examined in the stills, was the extent to which people, if they leaned against other people, let their mouths fall slack. We got that out of examining lots and lots of stills. It's the same principle. It's quite different if you have a thesis and have the camera in your hand, the chances of influencing the material are greater. When you don't have the camera in your hand, you can look at the things that happen in the background.

Bateson: There are three ends to this discussion. There's the 
sort of film I want to make, there's the sort of film that they want to make in New Mexico (which is Dead Birds, substantially), and there is the sort of film that is made by leaving the camera on a tripod and not paying attention to it.

$S B$ : Who does that?

Bateson: Oh, psychiatrists do that. Albert Scheflen [1973] leaves a video camera in somebody's house and goes home. It's stuck in the wall.

Mead: Well, I thoroughly disapprove of the people that want video so they won't have to look. They hand it over to an unfortunate student who then does the rest of the work and adds up the figures, and they write a book. We both object to this. But I do think if you look at your long sequences of stills, leave out the film for a minute, that those long, very rapid sequences, Koewat Raoeh, those stills, they're magnificent, and you can do a great deal with them. And if you hadn't stayed in the same place, you wouldn't have those sequences.

$S B$ : Has anyone else done that since?

Mead: Nobody has been as good a photographer as Gregory at this sort of thing. People are very unwilling to do it, very unwilling.

$S B$ : I haven't seen any books that come even close to Balinese Character [see Mead and Bateson 1942].

Mead: That's right, they never have. And now Gregory is saying it was wrong to do what he did in Bali. Gregory was the only person who was ever successful at taking stills and film at the same time, which you did by putting one on a tripod, and having both at the same focal length.

Bateson: It was having one in my hand and the other round my neck.

Mead: Some of the time, and some not.

Bateson: We used the tripod occasionally when we were using long telephoto lenses.

Mead: We used it for the bathing babies. I think the difference between art and science is that each artistic event is unique, whereas in science sooner or later once you get some kind of theory going somebody or other will make the same discovery [see Mead 1976]. The principal point is access, so that other people can look at your material and come to understand it and share it. The only real information that Dead Birds gives anybody are things like the thing that my imagination had never really encompassed, and that's the effect of cutting off joints of fingers. You remember? The women cut off a joint for every death that they mourn for, and they start when they're little girls, so that by the time they're grown women, they have no fingers. All the fine work is done by the men in that society, the crocheting and what not, because the men have fingers to do it with and the women have these stumps of hands. I knew about it, I had read about it, it had no meaning to me until I saw those pictures. There are lots of things that can be conveyed by this quasi-artistic film, but when we want to suggest to people that it's a good idea to know what goes on between people, which is what you've always stressed, we still have to show your films, because there aren't any others that are any thing like as good.

$S B$ : Isn't that a little shocking? It's been, what, years?

Mead: Very shocking.

Bateson: It's because people are getting good at putting cameras on tripods. It isn't what happens between people.

Mead: Nobody's put any cameras on tripods in those twenty-five years that looked at anything that mattered.

Bateson: They haven't looked at anything that mattered, anyway. All right.

\section{REFERENCES CITED}

Gardner, Robert, Director

1964 Dead Birds. Peabody Museum, Harvard University. Color, 83 minutes. Available through New York Public Library.

Mead, Margaret

1976 Towards a Human Science. Science 191:903-909.

Mead, M., and G. Bateson

1942 Balinese Character: A Photographic Analysis. New York Academy of Sciences; Special Publications, II. (Reissued 1962.)

Scheflen, Albert E.

1973 Body Language and the Social Order: Communication as Behavioral Control. Englewood Cliffs: Prentice-Hall.

Thompson, Betty

1970 Development and Trial Applications of Method for Identifying Non-Vocal Parent-Child Communications in Research Film. Ph.D. thesis, Teachers College.

Worth, Sol, and John Adair

1972 Through Navajo Eyes. Bloomington: Indiana University Press. [Intrepid Shadows was made by Al Clah, a 19-year old Navajo painter and sculptor.] 